\title{
LAJU DEGRADASI HABITAT MONYET HITAM SULAWESI (Macaca nigra) DI CAGAR ALAM GUNUNG DUASUDARA SULAWESI UTARA
}

\author{
Hanry J. Lengkong ${ }^{1)}$ \\ 1)Program Studi Biologi FMIPA Universitas Sam Ratulangi, Manado 95115 \\ e-mail: Hanry_lengkong@yahoo.co.id
}

\begin{abstract}
ABSTRAK
Penelitian ini bertujuan untuk mengamati keadaan habitat dan penyebaran monyet hitam sulawesi di Cagar Alam Gunung Duasudara, dan aktivitas masyarakat yang terkait dengan keberadaan monyet hitam sulawesi di sekitar kawasan. Pengamatan kondisi habitat (termasuk profil penggunaan stratum vegetasi) dan interaksi antara monyet hitam sulawesi dan penduduk sekitar kawasan telah dilakukan selama 4 bulan (Mei sampai dengan Agustus 2006). Metode pengamatan habitat difokuskan pada penggunaan stratum vegetasi dan pohon tidur monyet hitam sulawesi dan hasilnya digambarkan dalam bentuk diagram profil habitat. Wawancara kepada masyarakat sekitar kawasan juga dilakukan untuk mendapatkan informasi aktivitas masyarakat yang berhubungan dengan monyet hitam sulawesi. Dua stratum yang paling banyak digunakan untuk beraktifitas adalah stratum A dan B. Persentase pemanfaatannya yaitu sebesar $65,21 \%$. Karakteristik pohon yang digunakan sebagai pohon tidur antara lain dekat dengan sumber pakan dan minum, pohon yang tinggi dan besar, serta mempunyai percabangan yang banyak. Penyebaran populasi monyet hitam sulawesi tergantung pada ketersediaan sumber pakan dan perlindungan di dalam hutan. Tanpa usaha mengurangi perburuan dan perambahan hutan, populasi ini akan mengalami kepunahan.

Kata kunci : Gunung Duasudara, habitat, monyet hitam
\end{abstract}

\section{DEGRADATION RATE OF Macaca nigra HABITAT IN DUASUDARA NATURE RESERVE, NORTH SULAWESI}

\begin{abstract}
This research aimed to observe habitat condition and distribution of sulawesi-black macaques (Macaca nigra) in Duasudara Nature Reserve, and society activities that were related to existence of these macaques. A survey was conducted on the habitat condition (including utilization profile of vegetation stratum) and the interaction between macaques and local people around the nature reserve in May - Agustus 2006. Methods of observing habitat focused on using vegetation stratum and trees for sleepingly macaques. The results were presented as diagram of habitat profile. Activities of local people that were related to macaques were obtained by interviewing these people. Two stratum (A and B) were frequently used, i.e. 65,21\%. For sleeping, they preferred trees which were close to source of food and drink, high and big with many branches. Population distribution of macaques depended on the availability of food resources and protected area in the forest. The efforts to reduce hunting pressure and habitat loss are required to prevent macaques extinction.
\end{abstract}

Keywords: Duasudara mountain, habitat, black macaques

\section{PENDAHULUAN}

Monyet hitam sulawesi (Macaca nigra) adalah salah satu spesies Macaca dari 7 spesies Macaca yang ada di Sulawesi (Fooden 1969 dalam Whitten et al. 1987). Diantara 3 spesies Macaca di Sulawesi bagian utara ( $M$. nigra, M. nigrescens dan M.hecki), monyet hitam sulawesi merupakan jenis yang paling terancam keberadaannya. Hasil penelitian menunjukkan bahwa populasi maupun habitatnya semakin menurun dari tahun ke tahun. Kinnaird (1997) melaporkan bahwa, akibat perburuan dan pengrusakan habitat saja, populasi monyet hitam sulawesi di Cagar Alam (CA) Tangkoko Duasudara yang merupakan salah satu tempat ditemukannya kelompok ini, 
telah mengalami penurunan $75 \%$ sejak tahun 1979.

Cagar Alam Gunung Duasudara merupakan bagian dari kawasan Cagar Alam Tangkoko- Duasudara yang terletak di ujung tenggara semenanjung utara Kabupaten Minahasa. Kehadiran penduduk desa sekitar kawasan Cagar Alam Gunung Duasudara menimbulkan beberapa permasalahan yang secara langsung atau tidak langsung mengancam kehidupan monyet hitam sulawesi.

Permasalahan klasik yang dialami oleh hampir setiap negara terhadap keberadaan satwaliar termasuk satwa primata adalah masalah perburuan dan perambahan hutan. Masalah tersebut juga terjadi di Cagar Alam Gunung Duasudara. Ketergantungan masyarakat terhadap kawasan hutan dan hasil hutan yang sangat tinggi, memicu masyarakat untuk melakukan kegiatan perambahan hutan, penebangan liar, perburuan dan perdagangan liar. Belum lagi masalah lain yang tidak bisa dikendalikan seperti bencana alam (kebakaran), yang kerap terjadi di sekitar kawasan. Faktor lain yang ikut menambah semua tekanan di atas yaitu lemahnya pengelolaan kawasan lindung oleh pemerintah maupun pihat terkait.

Dalam rangka pembinaan dan pengelolaan kawasan guna menyelamatkan monyet hitam sulawesi diperlukan data dasar. Adapun data dan informasi terbaru mengenai habitat monyet hitam sulawesi dan aspek social budaya masyarakat di Cagar Alam Gunung Duasudara sampai saat ini masih sangat terbatas. Hal-hal inilah yang menjadi dasar mengapa penelitian ini perlu dilakukan.

\section{METODE PENELITIAN}

Penelitian ini dilaksanakan di Cagar Alam Gunung Duasudara, Sulawesi Utara. Waktu penelitian berlangsung selama 4 bulan yakni dari bulan Mei - Agustus 2006. Lokasi penelitian di bagi 3 jalur yaitu jalur A daerah Pinangunian, jalur B daerah Duasudara dan jalur $\mathrm{C}$ daerah Temboan. Pengamatan strata oleh monyet hitam sulawesi dikelompokkan sesuai dengan pembagian strata (5 stratum) dan dihitung presentase pemanfaatannya. Pengamatan pemanfaatan pohon tidur/makan monyet hitam sulawesi dengan membuat masing-masing satu plot vegetasi dengan ukuran 20 x $50 \mathrm{~m}$ dan data digambarkan dengan menggunakan Corel Draw 12. Sebaran kelompok monyet hitam sulawesi diperoleh dengan mencatat koordinat tempat ditemukan monyet hitam sulawesi dan memetakannya kedalam peta lokasi menggunakan Program Arcview GIS 3.2. Data hasil pengamatan dianalisis secara deskriptif.

\section{HASIL DAN PEMBAHASAN}

\section{Kondisi Habitat Cagar Alam Gunung Duasudara}

Sesuai dengan hasil pengamatan langsung di lapangan Mei- Agustus 2005, secara umum keadaan hutan CA Gunung Duasudara cukup memprihatinkan. Berbagai praktek perusakan hutan, masih sering terjadi di cagar alam ini. Perladangan berpindah, yang telah merambah kawasan cagar alam, terus dilakukan oleh penduduk yang berada di sekitar kawasan, dengan menanam tanaman perkebunan.

Salah satu contoh perambahan hutan untuk dijadikan areal perkebunan di daerah perbatasan antara Desa Pinangunian dan Cagar Alam Gunung Duasudara. Menurut informasi yang diperoleh dari pihak Lembaga Swadaya Masyarakat (LSM), yang melakukan patroli di kawasan Cagar Alam Tangkoko-Batuangus Duasudara, beberapa tahun yang lalu daerah tersebut masih baik dan layak sebagai habitat alami monyet hitam sulawesi. Perambahan hutan terjadi juga di daerah Temboan yang letaknya hampir berbatasan dengan CA Tangkoko-Batuangus. Beberapa penduduk memanfaatkan kawasan sebagai tempat untuk menggembalakan ternak.

\section{Pemanfaatan Stratum}

Persentase pemanfaatan stratum oleh monyet hitam sulawesi dapat dilihat pada Tabel 1 berikut ini.

Tabel 1. Persentase pemanfaatan stratum oleh monyet hitam sulawesi

\begin{tabular}{c|c}
\hline Stratum & Persentase pemanfaatan (\%) \\
\hline A & 30,43 \\
B & 34,78 \\
C & 13,04 \\
D & 8,71 \\
E & 13,04 \\
\hline
\end{tabular}


Data yang diperoleh menunjukkan bahwa monyet hitam sulawesi memanfaatkan semua bagian stratum. Stratum A dan B (tinggi lebih dari $10 \mathrm{~m}$ ) dengan persentase pemanfaatan $65,21 \%$, adalah dua bagian stratum yang paling banyak digunakan dalam beraktivitas. Stratum ini merupakan kumpulan pohon yang membentuk suatu kanopi tertutup dengan tajuk yang bersentuhan. Aktivitas yang dilakukan pada saat teramati adalah makan dan bergerak/berjalan.

Monyet hitam sulawesi menyukai bagian tepi tajuk pada kedua stratum ini karena bagian tumbuhan yang dimakan seperti buah, bunga dan pucuk daun muda berada pada tepi tajuk suatu individu pohon. Kesukaan monyet hitam sulawesi untuk bergerak pada kedua stratum ini terutama untuk berpindah dari satu pohon ke pohon lain, karena keadaan tajuk yang kontinu (saling bersentuhan) sehingga monyet hitam sulawesi dapat bergerak cepat tanpa harus berpindah stratum. Monyet hitam sulawesi juga memanfaatkan bagian stratum ini untuk bersembunyi, karena pada bagian ini terdapat percabangan pohon yang berukuran besar, terutama pada stratum B.

Lantai hutan (stratum E) digunakan oleh monyet hitam sulawesi untuk beristirahat atau duduk. Ketika beristirahat atau tidur, monyet hitam sulawesi lebih memilih stratum A dan B dengan ketinggian lebih dari $10 \mathrm{~m}$. Stratum D paling sedikit digunakan untuk beraktivitas. Biasanya digunakan oleh monyet hitam sulawesi untuk berpindah stratum dalam satu pohon yang sama. Alikodra (2002) menyatakan bahwa suatu masyarakat satwaliar dapat dibedakan menurut perbedaan lapisan hutan. Setiap stratum mempunyai kemampuan untuk mendukung kehidupan jenis-jenis satwaliar tertentu.

\section{Karakteristik Lokasi Pohon Tidur Monyet hitam sulawesi}

Monyet hitam sulawesi cenderung memilih pohon yang berukuran besar dan bercabang banyak, sehingga memungkinkan bagi seluruh anggotanya untuk tidur. Pohonpohon besar yang letaknya berdekatan dalam satu tempat lebih disukai. Percabangan yang banyak, dengan daun yang lebat, juga membantu monyet hitam sulawesi untuk menghindar dari gangguan predator ketika beristirahat.

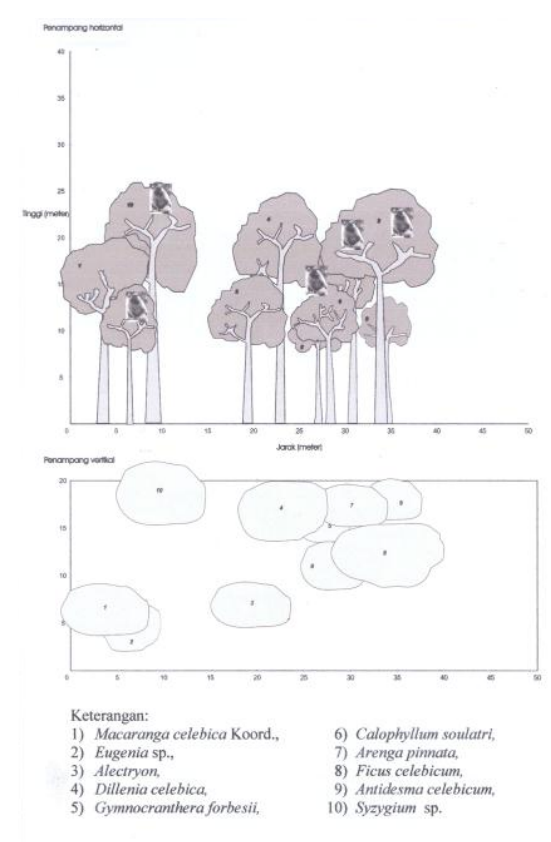

Gambar 1. Profil pohon tidur di jalur A
(daerah Pinangunian)

Profil pohon tidur pada jalur A (Gambar 1), terdapat pohon-pohon yang berukuran besar dengan diameter berkisar antara 20,2- 102,4 cm, serta tinggi pohon antara 13-26 m. Beberapa jenis pohon yang dijadikan tempat untuk tidur yaitu Macaranga celebica Koord., Eugenia sp. (jambu), Ficus celebicum dan Syzygium (pakoba). Keempat pohon ini memiliki percabangan yang banyak, dengan tinggi tajuk antara 9-15 m.

Sama halnya dengan jalur B (Gambar 1), pohon-pohon pada jalur ini memiliki ukuran yang besar, namun jumlahnya lebih banyak dari jalur A. Beberapa jenis pohon yang ada pada jalur A juga ditemukan pada jalur ini seperti Eugenia sp.(jambu) dan Syzygium (pakoba). Pada jalur B, jenis pohon lebih bervariasi jenisnya, dengan rata-rata tinggi pohon $16,58 \mathrm{~m}$, dan berdiameter antara 20,3-63,7 cm. Pohon-pohon yang digunakan oleh monyet hitam sulawesi untuk tidur yaitu Talauma candoli, Trema orientalis (ruku) dan Cananga odorata (kenanga).

Profil pohon tidur yang terletak pada jalur $\mathrm{C}$ berjarak kurang lebih $40 \mathrm{~m}$ dari sumber air. Letak pohon tidur yang dekat 
dengan air, bisa menjadi salah satu alasan yang membuat monyet hitam sulawesi memilih lokasi tersebut sebagai tempat beristirahat. Beberapa jenis pohon yang berukuran besar $(\mathrm{dbh}>30 \mathrm{~cm})$ yang terdapat di lokasi tersebut yaitu Arenga pinnata (seho), Myristica fatua, Cananga odorata (kenanga), Dendrocnide microstigma (sosoro), Gleditschia rolfei, Syzygium sp.(pakoba) dan Maranthes corymbosa. Ratarata pohon ini memiliki tinggi lebih dari 20 $\mathrm{m}$, dengan lebar tajuk 6-15 m.

Pada kesempatan yang lain di lokasi ini juga, monyet hitam sulawesi terlihat sedang mencari makan. Beberapa jenis pohon yang menjadi sumber pakan pada plot ini dan ditemukan juga pada lokasi sebelumnya yaitu Cananga odorata (kenanga), Syzygium sp. (pakoba), Arenga pinnata (seho), Eugenia sp. (jambu) dan beberapa jenis Ficus (beringin). Ficus termasuk jenis pakan yang melimpah di CA Tangkoko-Batuangus Duasudara. Selain berbuahnya tidak mengenal musim, Ficus kaya akan kandungan nutrisi terutama Calsium dan Magnesium (Kinnaird et all., 1999).

Menurut Alikodra (2002), beberapa jenis pohon (misalnya Ficus sp.) yang tajuknya berbentuk payung, sangat disukai oleh primata dan burung sebagai tempat berlindung, beristirahat dan sekaligus untuk mencari makan. Dikatakan pula bahwa struktur vegetasi suatu pohon sangat menentukan peranannya sebagai pelindung, terutama ditentukan oleh tajuk dan percabangannya. Lokasi pohon tidur yang digunakan biasanya lebih dari satu/berpindah-pindah. Hal ini bisa disebabkan oleh luasnya daerah jelajah ataupun ketersediaan pakan di hutan.

\section{Penyebaran Monyet hitam sulawesi}

Pergerakan monyet hitam sulawesi yang hidup di CA Gunung Duasudara sudah semakin jauh masuk ke dalam hutan. Monyet hitam sulawesi sudah sangat jarang ditemui di pinggir-pinggir hutan seperti beberapa puluh tahun yang lalu. Hal ini disebabkan oleh berkurangnya habitat tempat monyet hitam sulawesi hidup akibat perambahan hutan, dan faktor perburuan yang telah berlangsung bertahun-tahun. Pergerakan monyet hitam sulawesi ini secara tidak langsung mempengaruhi pola penyebarannya.
Monyet hitam sulawesi dapat hidup sampai pada ketinggian $2000 \mathrm{~m}$ dpl baik pada hutan primer, maupun sekunder (pesisir) (Supriatna \& Hendras 2000). Gambar 1, terlihat bahwa penyebaran monyet hitam sulawesi di daerah Pinangunian dan Duasudara cenderung sama, dimana titik-titik penyebaran memiliki jarak yang saling berdekatan. Pada daerah Temboan, penyebarannya lebih meluas. Hal ini disebabkan oleh kualitas habitat pada setiap jalur yang berbeda. Daerah Pinangunian dan Duasudara memiliki habitat yang lebih baik, dengan ketersediaan sumber-sumber pakan atau pohon yang mencukupi untuk monyet hitam sulawesi, dibandingkan pada jalur Temboan. Kesulitan dalam mencari sumber pakan merupakan salah satu penyebab mengapa monyet hitam sulawesi di daerah Temboan lebih menyebar daripada kedua daerah yang lain.

\section{Aktivitas Masyarakat di Sekitar Kawasan CA Gunung Duasudara.}

Sebagian besar penduduk di sekitar kawasan memiliki mata pencaharian sebagai petani. Tanaman yang paling banyak ditanam adalah jagung dan kelapa. Gangguan yang paling utama terhadap tanaman perkebunan adalah hama. Hama yang mengganggu tanaman yaitu tikus, babi hutan, serangga dan juga monyet hitam sulawesi. Jerat dan perangkap digunakan untuk menangkap monyet hitam sulawesi digunakan baik oleh petani maupun pemburu Ketika melakukan pengamatan habitat, ditemukan jerat dan perangkap monyet hitam sulawesi yang tidak digunakan lagi. Menurut salah seorang penduduk setempat, monyet hitam sulawesi kemungkinan sudah mengetahui bahwa itu adalah perangkap atau jerat yang berbahaya bagi mereka.

Beberapa satwa liar lain seperti tikus hutan, babi hutan, kelelawar, burung dan kuskus merupakan jenis-jenis yang masih diburu. Tikus hutan adalah jenis yang paling banyak diburu oleh penduduk. Menurut para penduduk, tikus tidak dilindungi oleh pemerintah dan populasinya masih banyak di hutan. Masyarakat biasanya memasang perangkap tikus (dodeso) di tempat-tempat yang biasa dilalui tikus di dalam hutan. Hasil buruan yang diperoleh sebagian dijual dan sisanya dikonsumsi sebagai lauk. Satwa liar (termasuk monyet hitam sulawesi) masih saja 
diburu secara diam-diam. Pada hari-hari yang dianggap istimewa oleh penduduk setempat, tidak jarang terlihat sajian daging monyet hitam sulawesi (monyet), diantara menu makanan yang tersedia.

Pada dasarnya masyarakat tahu bahwa monyet hitam sulawesi adalah binatang yang dilindungi. Mereka juga sependapat bahwa habitat satwaliar atau hutan adalah sesuatu yang perlu dijaga dan dilestarikan. Namun demikian, tuntutan kebutuhan hidup membuat penduduk terpaksa menjadikan hutan di sekitarnya sebagai tempat mencari makan dan bertani. Tuntutan untuk memenuhi kebutuhan hidup menjadi salah satu akar permasalahan yang dialami oleh penduduk yang tinggal di sekitar hutan atau kawasan yang dilindungi.

\section{KESIMPULAN}

Monyet hitam sulawesi memanfaatkan semua bagian strata dalam melakukan aktivitas. Stratum A dan B (tinggi lebih dari $10 \mathrm{~m}$ ) dengan persentase pemanfaatan $65,21 \%$, adalah dua bagian stratum yang paling banyak digunakan dalam beraktivitas. Pemilihan lokasi pohon tidur terutama di daerah yang tersedia sumber pakan dan minum, dengan karakteristik pohon yang tinggi, besar dan mempunyai percabangan yang banyak. Pohon yang membentuk suatu kanopi tertutup dengan tajuk yang bersentuhan lebih disukai. Pohonpohon yang digunakan sebagai pohon tidur antara lain Ficus spp., Eugenia, Zyzygium, dan Cananga odorata, Macaranga celebica Koord., Talauma candoli dan Trema orientalis.

Keadaan habitat di CA Gunung Duasudara saat ini secara umum semakin memburuk. Luas kawasan semakin mengecil akibat perambahan hutan. Sebagai respon terhadap perambahan hutan dan perburuan liar, monyet hitam sulawesi cenderung membentuk kelompok-kelompok dengan jumlah anggota yang kecil dan tingkah laku monyet hitam sulawesi pun menjadi semakin liar. Selain itu penyebarannya semakin jauh masuk ke dalam hutan. Pohon-pohon yang besar dan memiliki tajuk yang rapat pada habitat tersebut, digunakan oleh monyet hitam sulawesi untuk mencari makan, beristirahat atau berlindung terutama dari ancaman pemburu.

\section{DAFTAR PUSTAKA}

Alikodra, H. 1990. Pengelolaan Satwa Liar. Jilid 1. Departemen Pendidikan dan Kebudayaan Direktorat Jendral Pendidikan Tinggi Pusat Antar Universitas Ilmu Hayat Institut Pertanian Bogor.

Kinnaird, M.F. 1997. Sulawesi Utara. Sebuah Panduan Sejarah Alam. Jakarta: Percetakan Redikencana.

Kinnaird, M.F., T.G. O'Brien, dan S. Suryadi. 1999. The Importance of Figs to Sulawesi's Imperiled Wildlife. Tropical Biodiversity 6(1\&2):5-18

Supriatna, J., J.W. Hendras. 2000. Primata Indonesia. Panduan Lapangan. Jakarta: Yayasan Obor Indonesia.

Whitten, A.J. Mustafa, dan G.S. Henderson. 1987. Ekologi Sulawesi. Gadjah Mada University Press, Yogyakarta. 